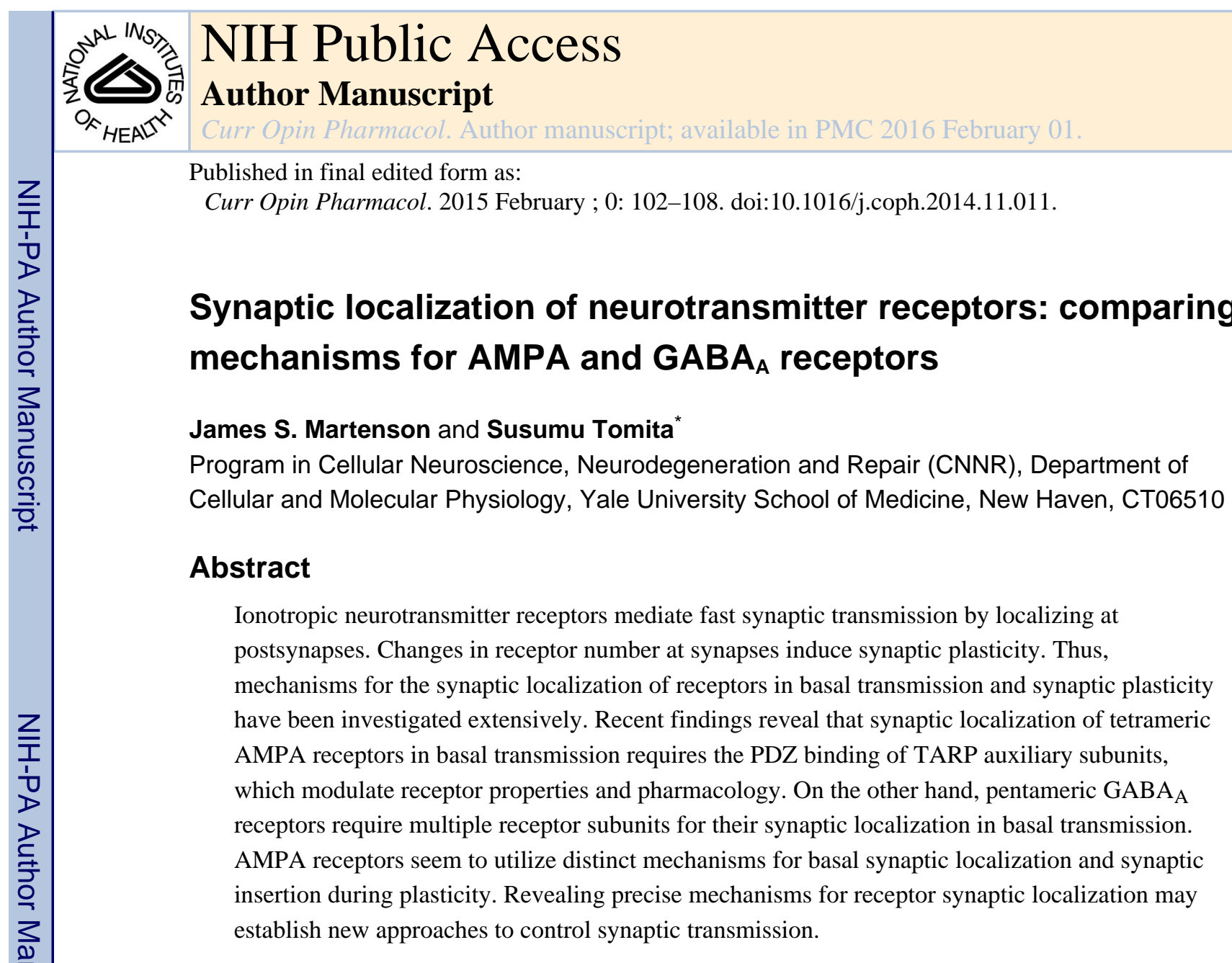

\title{
Introduction
}

Synaptic transmission is mediated by neurotransmitters and their receptors. The properties and number of receptors at synapses determine synaptic strength. It is thus of critical interest to reveal the molecular mechanisms determining both receptor properties and receptor number at synapses. In this review, we discuss recent progress toward understanding the synaptic localization of neurotransmitter receptors by comparing findings in AMPA receptors (AMPARs) for excitatory synapses and $\mathrm{GABA}_{\mathrm{A}}$ receptors $\left(\mathrm{GABA}_{\mathrm{A}} \mathrm{Rs}\right)$ for inhibitory synapses. To reveal mechanisms to stabilize receptors at postsynapses, significant effort has focused on gene knockout and overexpression strategies. However, interpretation of such studies is complicated by the fact that these manipulations may primarily alter receptor protein expression, assembly or trafficking, and secondarily affect the number of receptors at synapses. Thus, a robust alteration in receptor synaptic localization may be observed, but a direct mechanism to stabilize receptors at synapses may not be revealed.

\footnotetext{
(C) 2014 Elsevier Ltd. All rights reserved.

"To whom correspondence should be addressed: Yale University School of Medicine, 295 Congress Avenue BCMM441, New Haven, CT 06510, +1-203-785-7201, Susumu.Tomita@yale.edu.

Publisher's Disclaimer: This is a PDF file of an unedited manuscript that has been accepted for publication. As a service to our customers we are providing this early version of the manuscript. The manuscript will undergo copyediting, typesetting, and review of the resulting proof before it is published in its final citable form. Please note that during the production process errors may be discovered which could affect the content, and all legal disclaimers that apply to the journal pertain.
} 
Therefore, it is important to elucidate how molecules modify the activity and localization of receptors and to identify direct mechanisms to control receptor localization at synapses.

\section{Receptor complexes}

Both AMPARs and $\mathrm{GABA}_{\mathrm{A}}$ Rs are heterooligomeric ion channels comprised of distinct pore-forming subunits. Besides pore-forming subunits, native receptor complexes may contain auxiliary subunits that modulate receptor localization, properties and/or pharmacology.

Native AMPARs assemble with transmembrane AMPAR regulatory proteins (TARPs) auxiliary subunits (Figure 1a). TARPs accelerate AMPAR gating, change affinity and efficacy of pharmacological reagents and regulate the surface expression and synaptic localization of the receptors [1,2]. An additional component of the AMPAR complex, cornichon-like protein $(\mathrm{CNIH})$, was identified by a proteomic approach [3]. In the hippocampus, AMPARs form a tripartite complex with TARP $\gamma-8$ and $\mathrm{CNIH} 2$, and the expression of $\mathrm{CNIH} / 3$ and the AMPAR subunits GluA1 and GluA2 is significantly reduced in the hippocampus of TARP $\gamma-8$ knockout mice $[4,5]$. CNIH2 slows the decay kinetics of TARP $\gamma$-8/AMPARs, but not TARP $\gamma$-2/AMPARs [4,6,7]. CNIH2/3 knockout mice show reduced AMPA-evoked currents and accelerated decay kinetics of AMPAR-EPSCs [6], indicating that $\mathrm{CNIH}$ modulates the properties of AMPARs in the brain. Interestingly, in $C$. elegans, the cornichon homologue CNI-1 plays a role in AMPAR/GLR-1 trafficking [8]. Thus, CNIHs and TARPs may modulate both the properties and trafficking of AMPARs.

In addition to TARPs and CNIH2/3, recent proteomic studies identified GSG1-1 and CKAMP44, both of which modulate the AMPAR function [9-11]. Both CKAMP44 and GSG1-1 modulate AMPAR properties in heterologus cells, CKAMP44 knockout mice show changes in AMPAR responses upon repetitive stimulation in the hippocampal dentate gyrus [11], and CKAMP44 and TARP $\gamma-8$ co-operatively modulate AMPAR function [12]. It is likely that AMPARs in distinct brain regions form complexes with distinct sets of auxiliary subunits or interactors [13], thus enabling regional diversity of AMPAR function.

Native $\mathrm{GABA}_{A} \mathrm{Rs}$ are heteropentamers of distinct sets of $19 \mathrm{GABA}_{\mathrm{A}} \mathrm{R}$ subunits, and this combinatorial assembly provides diversity in $\mathrm{GABA}_{\mathrm{A}} \mathrm{R}$ function (Figure 1b) [14-16]. Concatenation of multiple $\mathrm{GABA}_{\mathrm{A}} \mathrm{R}$ subunits reveals that $\alpha 1 / \beta 2 / \gamma 2$-containing $\mathrm{GABA}_{\mathrm{A}} \mathrm{Rs}$ are arranged as $\beta 2-\alpha 1-\beta 2-\alpha 1-\gamma 2$ [17]. In contrast to AMPARs, no $\mathrm{GABA}_{\mathrm{A}} \mathrm{R}$ auxiliary subunit has been identified. Differences in receptor properties between $\mathrm{GABA}_{\mathrm{A}} \mathrm{Rs}$ expressed in neurons and heterologous cells have been observed [18]. However, given the diversity of $\mathrm{GABA}_{\mathrm{A}} \mathrm{R}$ subunits and the huge number of possible heteropentameric combinations of these subunits, it is difficult to know whether the differences in native and recombinant $\mathrm{GABA}_{\mathrm{A}} \mathrm{Rs}$ are due to differences in subunit combination, or to missing auxiliary subunits of the $\mathrm{GABA}_{\mathrm{A}} \mathrm{R}$ complex. A more thorough analysis of neuronal receptor properties with defined subunit composition will be helpful in identifying missing components of the native $\mathrm{GABA}_{\mathrm{A}} \mathrm{R}$ complex. 


\section{Subunits/domains responsible for synaptic localization}

The mechanisms of synaptic localization in basal transmission and synaptic plasticity have been studied extensively. These studies have generally focused on subunits or domains within the receptor complex that mediates synaptic localization, or on receptor interactors that anchor receptors at synapses. A challenge with this approach has been that many identified receptor interactors play no direct role in synaptic localization, but instead play important roles in receptor assembly, cell surface expression, and/or determining overall receptor protein level. Importantly, an alteration of receptor assembly, synaptic localization or subunit expression level can indirectly alter synaptic localization. Thus, experimental approaches are required to distinguish a domain/interactor's role in synaptic localization from its roles in other processes.

\section{Domains responsible for the synaptic localization of the AMPAR complex}

Cerebellar GCs of stargazer spontaneous mutant mice, in which TARP $\gamma-2$ expression is disrupted, display loss of AMPAR-EPSCs [19]. Overexpression of TARP $\gamma-2$ restores AMPAR-EPSCs in GCs from stargazer mice, while overexpression of a TARP $\gamma-2$ mutant lacking its PDZ binding domain restores surface activity of AMPARs, but not AMPAREPSCs [20]. This strongly supports a specific role of the TARP PDZ binding domain in determining synaptic AMPAR localization in basal transmission in cerebellar GCs. In the hippocampus of both TARP $\gamma-8$ knockout mice, as well as TARP $\gamma-8 \Delta 4$ knockin mice in which the last 4 amino acids of the PDZ binding domain are deleted, AMPAR-EPSCs are reduced only $30 \%$. This suggests that TARP $\gamma-8$ dependent AMPAR-EPSCs are mediated by the TARP $\gamma-8$ PDZ binding domain [5,21]. The mechanism for the residual 70\% of AMPAREPSCs in TARP $\gamma-8$ knockout and TARP $\gamma-8 \Delta 4$ mice remains unclear. It is possible that other TARP isoforms expressed in the hippocampus $(\gamma-2 / 3 / 4 / 5 / 7)$ play redundant roles in facilitating AMPAR-EPSCs, or that AMPARs in the hippocampus, in contrast to those in the cerebellum, may localize at synapses without TARPs. Consistent with a model wherein AMPARs localize to synapses in a TARP dependent manner, a TARP $\gamma-2 / 3 / 4$ triple knockout is lethal [22].

\section{Subunits responsible for the synaptic localization of $\mathrm{GABA}_{A} R \mathbf{s}$}

$\mathrm{GABA}_{\mathrm{A}}$ Rs are pentamers consisting of three distinct families of pore-forming subunits ( $a$, $\beta$, and non- $\alpha / \beta$ ) (Figure 1b). Each subunit has multiple isoforms that play redundant functions. Nonetheless, several knockout mice show a severe reduction in $\mathrm{GABA}_{\mathrm{A}} \mathrm{R}$-IPSCs. Three mechanisms might underlie a loss or reduction of GABA $A_{A}$-IPSCs: 1) A loss of synaptic $\mathrm{GABA}_{\mathrm{A}} \mathrm{Rs}$, due to a loss of $\mathrm{GABA}_{\mathrm{A}} \mathrm{R}$ expression, surface expression or synaptic localization; 2) a loss or reduction in $\mathrm{GABA}_{\mathrm{A}} \mathrm{R}$ conductance due to a change in $\mathrm{GABA}_{\mathrm{A}} \mathrm{R}$ properties or 3) defective GABA release from presynaptic terminals. Therefore, $G_{A B} A_{A} R$ knockout or knockin mice showing absent or reduced $\mathrm{GABA}_{\mathrm{A}} \mathrm{R}$-IPSCs should be examined in detail to distinguish between these possibilities.

A knockout mouse lacking expression of the subunit responsible for synaptic $\mathrm{GABA}_{\mathrm{A}} \mathrm{R}$ localization should show no or reduced $\mathrm{GABA}_{\mathrm{A}} \mathrm{R}$-IPSCs at synapses where this subunit is a major constituent, and such mutant mice have been described. For example, disruption of 
the $\beta 3$ or $\gamma 2$ subunit reduces GABA $_{A} R$ activity significantly [23-26]. Knock out of the $\beta 3$ subunit in mice reduces GABA-evoked whole-cell currents in both acutely dissociated and cultured neurons [24,26]. Most $\beta 3$ knockout mice die neonatally, supporting a critical role for $\beta 3$ in animal survival [24]. Primary cortical cultured neurons from $\beta 3$ knockout mice display $\mathrm{GABA}_{\mathrm{A}} \mathrm{R}$-miniature IPSCs (mIPSCs) with accelerated decay kinetics but normal amplitude [24]. This result indicates either that $\beta 3$ does not mediate synaptic localization, or that its function in synaptic localization is redundant with $\beta 1$ or $\beta 2$ subunits. Mice lacking expression of all three $\beta$ subunits might be a useful tool to reveal the roles of $\beta$ subunits in the brain. Neurons with disrupted $\gamma 2$ expression show an $80 \%$ reduction in $\mathrm{GABA}_{\mathrm{A}} \mathrm{R}$ mIPSC frequency [25]. Importantly, in primary cortical cultured neurons from $\gamma 2$ knockout mice, a 1 subunit does not localize at GAD-positive synapses, indicating that $\gamma 2$ modulates the synaptic localization of a 1 subunit. The synaptic localization of $\mathrm{GABA}_{\mathrm{A}} \mathrm{Rs}$ is restored by overexpression of the $\gamma 2$, but not $a 2$, subunit in $\gamma 2$ knockout neurons [27]. In addition, the $\gamma 2$ TM4 domain plays a critical role in synaptic localization [27], although the precise contribution of the $\gamma 2$ TM4 domain remains unclear. As mentioned above, besides the $\gamma 2$ and $\beta 3$ knockouts, other knockout mice, including a subunit knockouts, show reduced $\mathrm{GABA}_{\mathrm{A}} \mathrm{R}$-IPSCs. As strategies are developed to address complexities arising from $\mathrm{GABA}_{\mathrm{A}} \mathrm{R}$ heterogeneity and subunit redundancy in vivo, systematic analyses of the precise contributions of each subunit to receptor expression, assembly, surface expression and synaptic localization may become possible.

\section{Synaptic anchors and synaptic localization during plasticity}

Proteins enriched at excitatory and inhibitory synapses may anchor AMPARs and $\mathrm{GABA}_{\mathrm{A}} \mathrm{Rs}$, respectively.

\section{Excitatory synapses}

Many AMPAR/TARP interactors have been proposed to modulate AMPAR localization, and this diversity may reflect a high degree of complexity in the protein networks comprising the postsynaptic density (PSD) [28-31]. Due to space limitations, in this review we focus on PSD-95-like MAGUKs that interacts with the PDZ domain of TARPs responsible for synaptic localization of AMPARs.

A proteomic analysis identified the protein PSD-95 as a major PSD component [32]. PSD-95, along with other members of the PSD-95-like MAGUK protein family, associate with the TARP PDZ binding domain [20,33], and PSD-95 knockout mice show a reduction in AMPAR-EPSCs in basal transmission in the hippocampus [34,35]. These results suggest that PSD-95-like MAGUKs anchor AMPARs at synapses through TARPs. Interestingly, the interaction of PSD-95 with the TARP PDZ binding domain is regulated by TARP phosphorylation (Figure 2). TARP $\gamma-2$ is highly phosphorylated at synapses, and nine serine residues are phosphorylated in neurons [36]. TARP knockin mice, in which all nine serine residues are replaced with either alanine (non-phospho mimic) or aspartic acid (phosphomimic), were generated. Whereas phospho-mimic TARP $\gamma-2$ knockin mice show increased AMPAR-EPSCs at the cerebellar MF-GC synapses, non-phospho-mimic TARP $\gamma$ - 2 knockin mice show a reduction in AMPAR-EPSCs [37]. Phosphorylating TARPs or neutralizing negative chargd lipids dissociates TARPs from lipids, enhances TARP binding to PSD-95 in 
vitro, and increases AMPAR-EPSCs in neurons [37]. These results show the importance of TARP phosphorylation in basal transmission.

One challenge in studying mechanisms of AMPAR synaptic localization is that the number of AMPARs at synapses is dynamically regulated during synaptic plasticity [38]. Recent findings suggest that AMPARs may localize to synapses under basal conditions and during synaptic plasticity by distinct mechanisms (Figure 2). Whereas AMPAR-EPSCs in basal transmission are reduced in a PSD-95 knockout mouse, long-term potentiation (LTP) is enhanced $[34,35,39]$. Complementing these findings, TARP $\gamma-8$ knockout mice display a severe reduction in LTP, whereas normal LTP is observed in TARP $\gamma-8 \Delta 4$ mice lacking the PDZ binding domain [5,21]. These results indicate a critical role for the TARP-PSD-95 interaction in basal transmission, but not in LTP. LTP requires insertion of AMPARs into synapses. In the simplest case, disrupting the mechanism for AMPAR insertion during LTP would block LTP without affecting basal transmission. GluA1 knockout mice and GluA1 double phospho-knockin mice show normal basal transmission but disrupted LTP [40,41], suggesting that the GluA1 subunit somehow facilitates AMPAR synaptic insertion during LTP. Recently, however, a reserve pool of glutamate receptors for LTP was shown to be independent from AMPARs. In neurons with disrupted all AMPAR expression, overexpressed KARs are inserted into synapses upon LTP induction [42]. The mechanism for how this reserve pool of receptors is stabilized, then translocated to the synapse during LTP, remains unclear.

\section{Inhibitory synapses}

Among molecules enriched at inhibitory postsynapses, gephyrin and neuroligin-2 have received particular attention, and their molecular links with $\mathrm{GABA}_{\mathrm{A}} \mathrm{Rs}$ have been extensively studied.

Gephyrin has been widely used as a marker for inhibitory synapses (Figure 1b). Gephyrin was originally co-purified with glycine receptors from an amino-strychnine affinity-column [43], and was subsequently found to localize to both glycinergic and GABAergic inhibitory synapses [44]. $\mathrm{GABA}_{\mathrm{A}}$ Rs and gephyrin may mutually stabilize each other at synapses. Spinal cord and primary hippocampal cultured neurons from gephyrin knockout mice show a reduction in synaptic localization of some, but not all, $\mathrm{GABA}_{\mathrm{A}} \mathrm{R}$ subunits [45], supporting a model in which $\mathrm{GABA}_{\mathrm{A}}$ Rs localize to synapses by both gephyrin dependent and independent mechanisms. On the other hand, disruption of the $\mathrm{GABA}_{A} \mathrm{R} \gamma 2$ or a subunits redistributes gephyrin from synapses [25,46-48], and interaction of gephyrin with $\alpha$ and $\beta$ subunits has been shown [49-51]. These results support a model in which $\mathrm{GABA}_{\mathrm{A}} \mathrm{Rs}$ first stabilize gephyrin at GABAergic synapses, followed by gephyrin-dependent recruitment of additional synaptic $\mathrm{GABA}_{\mathrm{A}} \mathrm{Rs}$ [52]. Importantly, a molecule initiating the synaptic localization of $\mathrm{GABA}_{\mathrm{A}}$ Rs and gephyrin remains unidentified.

The neuroligin-neurexin complex plays a critical role in synaptic transmission. Neuroligin-2 (NL2) is enriched at inhibitory synapses, whereas NL1 is enriched at excitatory synapses [53,54] (Figure 1). Postsynaptic overexpression of NL2 promotes the formation of both excitatory and inhibitory synapses in primary cultured neurons, whereas overexpression of NL1 or NL3 preferentially promotes excitatory synapse formation, suggesting that NL2 
predominantly acts at inhibitory postsynapses [54,55]. Two models have been proposed by which NL2-neurexin may regulate $\mathrm{GABA}_{\mathrm{A}}$ Rs. First, the cytoplasmic domain of NLs may interact with gephyrin and collybistin to induce synaptic localization of $\mathrm{GABA}_{\mathrm{A}} \mathrm{Rs}$ [56,57]. Supporting this model, knocking out any one of these three components in mice reduces $\mathrm{GABA}_{\mathrm{A}} \mathrm{R}$-mIPSCs $[45,55,56,58]$, although in each case some $\mathrm{GABA}_{\mathrm{A}} \mathrm{Rs}$ remain at synapses, possibly due to redundancy by other isoforms, for example, NL4 [59]. On the other hand, postsynaptic neurexin interacts directly with $\mathrm{GABA}_{\mathrm{A}}$ Rs to modulate their function, but not their synaptic localization, by a NL-independent mechanism [60]. Stoichiometric information about the native $\mathrm{GABA}_{\mathrm{A}} \mathrm{R} /$ neurexin complex in the brain may reveal key details about this mechanism. Similar to gephyrin and NL2, the dystrophinglycoprotein complex (DGC) is also enriched in GABAergic synapses [61]. GABA ${ }_{A}$ Rs are redistributed in dystrophin mutant mice [62]. However, in primary hippocampal neurons, disrupting the expression of dystroglycan, a critical DGC component, does not alter the distribution of $\mathrm{GABA}_{\mathrm{A}} \mathrm{Rs}$ [63]. Thus, there appears to be heterogeneity in the requirement for $\mathrm{DGC}$ in $\mathrm{GABA}_{\mathrm{A}} \mathrm{R}$ clustering at synapses.

Recently, the ADAMTS like protein Madd-4 was identified as a modulator of $\mathrm{GABA}_{\mathrm{A}} \mathrm{R}$ synaptic localization by C. elegans genetic screening [64](Figure 1b). In Madd-4 mutants, both L-AchRs and $\mathrm{GABA}_{\mathrm{A}}$ Rs redistribute to extrasynaptic sites. MADD-4 has long and short splicing isoforms, which result from alternative promoters. Selective deletion of the short isoform causes $\mathrm{GABA}_{\mathrm{A}} \mathrm{Rs}$ to redistribute to cholinergic synapses, whereas overexpression of the long isoform in GABAergic neurons recruites L-AChR to GABAergic synapses. These results suggest that MADD-4 is a critical synaptic organizer of both GABAergic and cholinergic synapses in C. elegans. It will be interesting to see whether the mammalian homologue of MADD-4, Punctin, regulates synaptic localization of GABA ${ }_{A}$ Rs.

\section{Conclusions}

Following neurotransmitter release, synaptic strength is determined by the properties and number of neurotransmitter receptors at postsynapses. Recent findings have shed light on mechanisms for the synaptic localization of neurotransmitter receptors. Here we compare mechanisms for the synaptic localization of tetrameric AMPARs and pentameric $\mathrm{GABA}_{\mathrm{A}} \mathrm{Rs}$ by focusing on the constituents of the respective receptor complexes in vivo, and the domains and interactors responsible for their synaptic localization. Although many interactors have been proposed as described above, due to the limited space in this review we focused on the role of PSD-95 like MAGUKs in the synaptic localization of the AMPAR/TARP complex, and the role of gephyrin, NL2 and MADD-4/Punctin in the synaptic localization of $\mathrm{GABA}_{\mathrm{A}}$ Rs. Figure 1 highlights interesting similarities and differences in our current understanding of AMPAR and $\mathrm{GABA}_{\mathrm{A}} \mathrm{R}$ synaptic localization. Neurexin-neuroligin complexes may play roles in regulating both AMPARs and $\mathrm{GABA}_{\mathrm{A}} \mathrm{Rs}$ through intermediate interactors. On the other hand, AMPARs have auxiliary subunits, but $\mathrm{GABA}_{\mathrm{A}} \mathrm{R}$ auxiliary subunits have not yet been found. Determining whether $\mathrm{GABA}_{\mathrm{A}} \mathrm{Rs}$ utilize auxiliary subunits will be a key step toward elucidating their mechanism of synaptic localization.

Curr Opin Pharmacol. Author manuscript; available in PMC 2016 February 01. 
As further insight is gained into the manner by which receptors localize to synapses, general principles governing the synaptic localization of all receptors may emerge. On the other hand, it may become apparent that each receptor type localizes to synapses via a distinct mechanism. Because distinct mechanisms corresponding to distinct receptor types could serve as targets for drug discovery, a complete understanding of these mechanisms may allow us to develop therapeutic strategies to manipulate synaptic activity rapidly in patients with neuropsychiatric disease.

\section{Acknowledgments}

The authors thank members of the Tomita lab for helpful discussions. S.T. is supported by NIH MH077939, MH085080 and J.S.M is supported by a NIH F30 M.D./Ph.D. fellowship F30MH099742 and the NIH Medical Scientist Training Program Training Grant T32GM007205.

\section{References and recommended reading}

1. Jackson AC, Nicoll RA. The expanding social network of ionotropic glutamate receptors: Tarps and other transmembrane auxiliary subunits. Neuron. 2011; 70(2):178-199. [PubMed: 21521608]

2. Yan D, Tomita S. Defined criteria for auxiliary subunits of glutamate receptors. J Physiol. 2012; 590(Pt 1):21-31. [PubMed: 21946847]

3. Schwenk J, Harmel N, Zolles G, Bildl W, Kulik A, Heimrich B, Chisaka O, Jonas P, Schulte U, Fakler B, Klocker N. Functional proteomics identify cornichon proteins as auxiliary subunits of ampa receptors. Science. 2009; 323(5919):1313-1319. [PubMed: 19265014]

4. Kato AS, Gill MB, Ho MT, Yu H, Tu Y, Siuda ER, Wang H, Qian YW, Nisenbaum ES, Tomita S, Bredt DS. Hippocampal ampa receptor gating controlled by both tarp and cornichon proteins. Neuron. 2010; 68(6):1082-1096. [PubMed: 21172611]

*5. Sumioka A, Brown TE, Kato AS, Bredt DS, Kauer JA, Tomita S. Pdz binding of tarpgamma-8 controls synaptic transmission but not synaptic plasticity. Nat Neurosci. 2011; 14(11):14101412. This study showed that the PDZ binding domain of TARP $\gamma-8$ is required for basal AMPAR transmission, but not for LTP, indicating that synaptic AMPARs localize at synapses via distinct mechanisms in basal transmission and during plasticity. [PubMed: 22002768]

*6. Herring BE, Shi Y, Suh YH, Zheng CY, Blankenship SM, Roche KW, Nicoll RA. Cornichon proteins determine the subunit composition of synaptic ampa receptors. Neuron. 2013; 77(6): 1083-1096. This study showed the functional significance of cornichon on AMPAR activity in the hippocampus using knockout mice and knockdown neurons. [PubMed: 23522044]

7. Gill MB, Kato AS, Wang H, Bredt DS. Ampa receptor modulation by cornichon- 2 dictated by transmembrane ampa receptor regulatory protein isoform. Eur J Neurosci. 2012; 35(2):182-194. [PubMed: 22211840]

*8. Brockie PJ, Jensen M, Mellem JE, Jensen E, Yamasaki T, Wang R, Maxfield D, Thacker C, Hoerndli F, Dunn PJ, Tomita S, et al. Cornichons control er export of ampa receptors to regulate synaptic excitability. Neuron. 2013; 80(1):129-142. This study showed that Cornichon controls AMPAR trafficking in C.elegans. [PubMed: 24094107]

9. Schwenk J, Harmel N, Brechet A, Zolles G, Berkefeld H, Muller CS, Bildl W, Baehrens D, Huber B, Kulik A, Klocker N, et al. High-resolution proteomics unravel architecture and molecular diversity of native ampa receptor complexes. Neuron. 2012; 74(4):621-633. [PubMed: 22632720]

10. Shanks NF, Savas JN, Maruo T, Cais O, Hirao A, Oe S, Ghosh A, Noda Y, Greger IH, Yates JR 3rd, Nakagawa T. Differences in ampa and kainate receptor interactomes facilitate identification of ampa receptor auxiliary subunit gsg11. Cell reports. 2012; 1(6):590-598. [PubMed: 22813734]

11. von Engelhardt J, Mack V, Sprengel R, Kavenstock N, Li KW, Stern-Bach Y, Smit AB, Seeburg $\mathrm{PH}$, Monyer H. Ckamp44: A brain-specific protein attenuating short-term synaptic plasticity in the dentate gyrus. Science. 2010; 327(5972):1518-1522. [PubMed: 20185686] 
12. Khodosevich K, Jacobi E, Farrow P, Schulmann A, Rusu A, Zhang L, Sprengel R, Monyer H, von Engelhardt J. Coexpressed auxiliary subunits exhibit distinct modulatory profiles on ampa receptor function. Neuron. 2014; 83(3):601-615. [PubMed: 25066086]

**13. Schwenk J, Baehrens D, Haupt A, Bildl W, Boudkkazi S, Roeper J, Fakler B, Schulte U. Regional diversity and developmental dynamics of the ampa-receptor proteome in the mammalian brain. Neuron. 2014; 84(1):41-54. This study showed diversity of native AMPAR complex in brain regions and developments using high-resolution proteomic approach. [PubMed: 25242221]

14. Sigel E, Steinmann ME. Structure, function, and modulation of gaba(a) receptors. J Biol Chem. 2012; 287(48):40224-40231. [PubMed: 23038269]

15. Olsen RW, Sieghart W. International union of pharmacology. Lxx. Subtypes of gammaaminobutyric acid(a) receptors: Classification on the basis of subunit composition, pharmacology, and function Update. Pharmacol Rev. 2008; 60(3):243-260. [PubMed: 18790874]

16. Fritschy JM, Panzanelli P, Tyagarajan SK. Molecular and functional heterogeneity of gabaergic synapses. Cellular and molecular life sciences : CMLS. 2012; 69(15):2485-2499. [PubMed: 22314501]

17. Baur R, Minier F, Sigel E. A gaba(a) receptor of defined subunit composition and positioning: Concatenation of five subunits. FEBS letters. 2006; 580(6):1616-1620. [PubMed: 16494876]

18. Verdoorn TA, Draguhn A, Ymer S, Seeburg PH, Sakmann B. Functional properties of recombinant rat gabaa receptors depend upon subunit composition. Neuron. 1990; 4(6):919-928. [PubMed: 1694446]

19. Hashimoto K, Fukaya M, Qiao X, Sakimura K, Watanabe M, Kano M. Impairment of ampa receptor function in cerebellar granule cells of ataxic mutant mouse stargazer. J Neurosci. 1999; 19(14):6027-6036. [PubMed: 10407040]

20. Chen L, Chetkovich DM, Petralia RS, Sweeney NT, Kawasaki Y, Wenthold RJ, Bredt DS, Nicoll RA. Stargazin regulates synaptic targeting of ampa receptors by two distinct mechanisms. Nature. 2000; 408(6815):936-943. [PubMed: 11140673]

21. Rouach N, Byrd K, Petralia RS, Elias GM, Adesnik H, Tomita S, Karimzadegan S, Kealey C, Bredt DS, Nicoll RA. Tarp gamma-8 controls hippocampal ampa receptor number, distribution and synaptic plasticity. Nat Neurosci. 2005; 8(11):1525-1533. [PubMed: 16222232]

22. Menuz K, O'Brien JL, Karmizadegan S, Bredt DS, Nicoll RA. Tarp redundancy is critical for maintaining ampa receptor function. J Neurosci. 2008; 28(35):8740-8746. [PubMed: 18753375]

23. Gunther U, Benson J, Benke D, Fritschy JM, Reyes G, Knoflach F, Crestani F, Aguzzi A, Arigoni M, Lang Y, et al. Benzodiazepine-insensitive mice generated by targeted disruption of the gamma 2 subunit gene of gamma-aminobutyric acid type a receptors. Proc Natl Acad Sci U S A. 1995; 92(17):7749-7753. [PubMed: 7644489]

24. Homanics GE, DeLorey TM, Firestone LL, Quinlan JJ, Handforth A, Harrison NL, Krasowski MD, Rick CE, Korpi ER, Makela R, Brilliant MH, et al. Mice devoid of gamma-aminobutyrate type a receptor beta3 subunit have epilepsy, cleft palate, and hypersensitive behavior. Proc Natl Acad Sci U S A. 1997; 94(8):4143-4148. [PubMed: 9108119]

*25. Essrich C, Lorez M, Benson JA, Fritschy JM, Luscher B. Postsynaptic clustering of major gabaa receptor subtypes requires the gamma 2 subunit and gephyrin. Nat Neurosci. 1998; 1(7):563571. This study showed that the $\gamma 2 \mathrm{GABA}_{\mathrm{A}} \mathrm{R}$ subunit is required for the synaptic localization of $\mathrm{GABA}_{A} \mathrm{Rs}$ and gephyrin in primary cortical cultured neurons, suggesting that the $\gamma 2$ subunit is required for synaptic localization. [PubMed: 10196563]

26. Ramadan E, Fu Z, Losi G, Homanics GE, Neale JH, Vicini S. Gaba(a) receptor beta3 subunit deletion decreases alpha2/3 subunits and ipsc duration. J Neurophysiol. 2003; 89(1):128-134. [PubMed: 12522165]

27. Alldred MJ, Mulder-Rosi J, Lingenfelter SE, Chen G, Luscher B. Distinct gamma2 subunit domains mediate clustering and synaptic function of postsynaptic gabaa receptors and gephyrin. $\mathrm{J}$ Neurosci. 2005; 25(3):594-603. [PubMed: 15659595]

28. Kim E, Sheng M. Pdz domain proteins of synapses. Nat Rev Neurosci. 2004; 5(10):771-781. [PubMed: 15378037] 
29. Scannevin RH, Huganir RL. Postsynaptic organization and regulation of excitatory synapses. Nature Reviews Neuroscience. 2000; 1(2):133-141.

30. Feng W, Zhang M. Organization and dynamics of pdz-domain-related supramodules in the postsynaptic density. Nat Rev Neurosci. 2009; 10(2):87-99. [PubMed: 19153575]

31. Bayes A, Grant SG. Neuroproteomics: Understanding the molecular organization and complexity of the brain. Nat Rev Neurosci. 2009; 10(9):635-646. [PubMed: 19693028]

32. Cho KO, Hunt CA, Kennedy MB. The rat brain postsynaptic density fraction contains a homolog of the drosophila discs-large tumor suppressor protein. Neuron. 1992; 9(5):929-942. [PubMed: 1419001]

33. Dakoji S, Tomita S, Karimzadegan S, Nicoll RA, Bredt DS. Interaction of transmembrane ampa receptor regulatory proteins with multiple membrane associated guanylate kinases. Neuropharmacology. 2003; 45(6):849-856. [PubMed: 14529722]

**34. Beique JC, Lin DT, Kang MG, Aizawa H, Takamiya K, Huganir RL. Synapse-specific regulation of ampa receptor function by psd-95. Proc Natl Acad Sci U S A. 2006; 103(51): 19535-19540. This study showed that AMPAR-EPSCs in basal transmission are decreased in PSD-95 knockout mice, whereas LTP is enhanced. This result suggests distinct mechanisms for synaptic AMPAR activity under basal conditions and during LTP. [PubMed: 17148601]

35. Carlisle HJ, Fink AE, Grant SG, O’Dell TJ. Opposing effects of psd-93 and psd-95 on long-term potentiation and spike timing-dependent plasticity. J Physiol. 2008; 586(Pt 24):5885-5900. [PubMed: 18936077]

36. Tomita S, Stein V, Stocker TJ, Nicoll RA, Bredt DS. Bidirectional synaptic plasticity regulated by phosphorylation of stargazin-like tarps. Neuron. 2005; 45(2):269-277. [PubMed: 15664178]

37. Sumioka A, Yan D, Tomita S. Tarp phosphorylation regulates synaptic ampa receptors through lipid bilayers. Neuron. 2010; 66(5):755-767. [PubMed: 20547132]

38. Huganir RL, Nicoll RA. Ampars and synaptic plasticity: The last 25 years. Neuron. 2013; 80(3): 704-717. [PubMed: 24183021]

**39. Migaud M, Charlesworth P, Dempster M, Webster LC, Watabe AM, Makhinson M, He Y, Ramsay MF, Morris RG, Morrison JH, O'Dell TJ, et al. Enhanced long-term potentiation and impaired learning in mice with mutant postsynaptic density-95 protein. Nature. 1998; 396(6710): 433-439. This study demonstrated enhanced LTP in PSD-95 knockout mice without changes in basal AMPAR activity. However, the group's following paper [21] showed reduced basal AMPAR activity in PSD-95 knockout mice, suggesting that enahanced LTP might be due to a reduction in basal AMPAR tranmission. [PubMed: 9853749]

40. Zamanillo D, Sprengel R, Hvalby O, Jensen V, Burnashev N, Rozov A, Kaiser KM, Koster HJ, Borchardt T, Worley P, Lubke J, et al. Importance of ampa receptors for hippocampal synaptic plasticity but not for spatial learning. Science. 1999; 284(5421):1805-1811. [PubMed: 10364547]

41. Lee HK, Takamiya K, Han JS, Man H, Kim CH, Rumbaugh G, Yu S, Ding L, He C, Petralia RS, Wenthold RJ, et al. Phosphorylation of the ampa receptor glur1 subunit is required for synaptic plasticity and retention of spatial memory. Cell. 2003; 112(5):631-643. [PubMed: 12628184]

**42. Granger AJ, Shi Y, Lu W, Cerpas M, Nicoll RA. LTP requires a reserve pool of glutamate receptors independent of subunit type. Nature. 2012 This study showed that any GluA or GluK1 can restored LTP in neurons lacking all AMPAR expressions. The magnitude of LTP mediated by these receptors correlated with their level of extrasynaptic surface expression, implicating a role for a reserve surface pool of receptors in LTP.

43. Pfeiffer F, Graham D, Betz H. Purification by affinity chromatography of the glycine receptor of rat spinal cord. J Biol Chem. 1982; 257(16):9389-9393. [PubMed: 6286620]

44. Sassoe-Pognetto M, Kirsch J, Grunert U, Greferath U, Fritschy JM, Mohler H, Betz H, Wassle H. Colocalization of gephyrin and gabaa-receptor subunits in the rat retina. J Comp Neurol. 1995; 357(1):1-14. [PubMed: 7673460]

45. Kneussel M, Brandstatter JH, Laube B, Stahl S, Muller U, Betz H. Loss of postsynaptic gaba(a) receptor clustering in gephyrin-deficient mice. J Neurosci. 1999; 19(21):9289-9297. [PubMed: 10531433]

46. Kralic JE, Sidler C, Parpan F, Homanics GE, Morrow AL, Fritschy JM. Compensatory alteration of inhibitory synaptic circuits in cerebellum and thalamus of gamma-aminobutyric acid type a 
receptor alpha1 subunit knockout mice. J Comp Neurol. 2006; 495(4):408-421. [PubMed: 16485284]

47. Studer R, von Boehmer L, Haenggi T, Schweizer C, Benke D, Rudolph U, Fritschy JM. Alteration of gabaergic synapses and gephyrin clusters in the thalamic reticular nucleus of gabaa receptor alpha3 subunit-null mice. Eur J Neurosci. 2006; 24(5):1307-1315. [PubMed: 16987218]

48. Panzanelli P, Gunn BG, Schlatter MC, Benke D, Tyagarajan SK, Scheiffele P, Belelli D, Lambert JJ, Rudolph U, Fritschy JM. Distinct mechanisms regulate gabaa receptor and gephyrin clustering at perisomatic and axo-axonic synapses on ca1 pyramidal cells. J Physiol. 2011; 589(Pt 20):4959_ 4980. [PubMed: 21825022]

49. Mukherjee J, Kretschmannova K, Gouzer G, Maric HM, Ramsden S, Tretter V, Harvey K, Davies PA, Triller A, Schindelin H, Moss SJ. The residence time of gaba(a)rs at inhibitory synapses is determined by direct binding of the receptor alpha1 subunit to gephyrin. J Neurosci. 2011; 31(41): 14677-14687. [PubMed: 21994384]

50. Maric HM, Mukherjee J, Tretter V, Moss SJ, Schindelin H. Gephyrin-mediated gammaaminobutyric acid type a and glycine receptor clustering relies on a common binding site. J Biol Chem. 2011; 286(49):42105-42114. [PubMed: 22006921]

51. Kowalczyk S, Winkelmann A, Smolinsky B, Forstera B, Neundorf I, Schwarz G, Meier JC. Direct binding of gabaa receptor beta2 and beta3 subunits to gephyrin. Eur J Neurosci. 2013; 37(4):544554. [PubMed: 23205938]

52. Levi S, Logan SM, Tovar KR, Craig AM. Gephyrin is critical for glycine receptor clustering but not for the formation of functional gabaergic synapses in hippocampal neurons. J Neurosci. 2004; 24(1):207-217. [PubMed: 14715953]

53. Varoqueaux F, Jamain S, Brose N. Neuroligin 2 is exclusively localized to inhibitory synapses. European journal of cell biology. 2004; 83(9):449-456. [PubMed: 15540461]

54. Graf ER, Zhang X, Jin SX, Linhoff MW, Craig AM. Neurexins induce differentiation of gaba and glutamate postsynaptic specializations via neuroligins. Cell. 2004; 119(7):1013-1026. [PubMed: 15620359]

55. Chih B, Engelman H, Scheiffele P. Control of excitatory and inhibitory synapse formation by neuroligins. Science. 2005; 307(5713):1324-1328. [PubMed: 15681343]

**56. Poulopoulos A, Aramuni G, Meyer G, Soykan T, Hoon M, Papadopoulos T, Zhang M, Paarmann I, Fuchs C, Harvey K, Jedlicka P, et al. Neuroligin 2 drives postsynaptic assembly at perisomatic inhibitory synapses through gephyrin and collybistin. Neuron. 2009; 63(5):628-642. This study showed that neuroligin-2 promotes the differentiation of perisomatic inhibitory postsynapses thorough the gephyrin and collybistin complex. Collybistin is activated by NL-2, thus enabling its association with the plasma membrane and further stabilizing the gephyrincollybistin complex at postsynapses. [PubMed: 19755106]

**57. Soykan T, Schneeberger D, Tria G, Buechner C, Bader N, Svergun D, Tessmer I, Poulopoulos A, Papadopoulos T, Varoqueaux F, Schindelin H, et al. A conformational switch in collybistin determines the differentiation of inhibitory postsynapses. EMBO J. 2014 This study showed a novel mechanism to regulate a complex composed of Neuroligin-2 and gephyrin through collybistin.

58. Papadopoulos T, Korte M, Eulenburg V, Kubota H, Retiounskaia M, Harvey RJ, Harvey K, O'Sullivan GA, Laube B, Hulsmann S, Geiger JR, et al. Impaired gabaergic transmission and altered hippocampal synaptic plasticity in collybistin-deficient mice. EMBO J. 2007; 26(17):38883899. [PubMed: 17690689]

59. Hoon M, Soykan T, Falkenburger B, Hammer M, Patrizi A, Schmidt KF, Sassoe-Pognetto M, Lowel S, Moser T, Taschenberger H, Brose N, et al. Neuroligin-4 is localized to glycinergic postsynapses and regulates inhibition in the retina. Proc Natl Acad Sci U S A. 2011; 108(7):30533058. [PubMed: 21282647]

*60. Zhang C, Atasoy D, Arac D, Yang X, Fucillo MV, Robison AJ, Ko J, Brunger AT, Sudhof TC. Neurexins physically and functionally interact with gaba(a) receptors. Neuron. 2010; 66(3):403416. This study showed that overexpresed neurexins inhibit $\mathrm{GABA}_{\mathrm{A}} \mathrm{R}$ activity in a cellautonomous, neuroligin-independent manner, and that neurexins can interact with $\mathrm{GABA}_{\mathrm{A}} \mathrm{Rs}$ in vitro, suggesting that neurexins may play a postsynaptic role in regulating $\mathrm{GABA}_{\mathrm{A}} \mathrm{R}$ function. [PubMed: 20471353] 
61. Waite A, Brown SC, Blake DJ. The dystrophin-glycoprotein complex in brain development and disease. Trends Neurosci. 2012; 35(8):487-496. [PubMed: 22626542]

62. Knuesel I, Mastrocola M, Zuellig RA, Bornhauser B, Schaub MC, Fritschy JM. Short communication: Altered synaptic clustering of gabaa receptors in mice lacking dystrophin ( $\mathrm{mdx}$ mice). Eur J Neurosci. 1999; 11(12):4457-4462. [PubMed: 10594673]

63. Levi S, Grady RM, Henry MD, Campbell KP, Sanes JR, Craig AM. Dystroglycan is selectively associated with inhibitory gabaergic synapses but is dispensable for their differentiation. $\mathrm{J}$ Neurosci. 2002; 22(11):4274-4285. [PubMed: 12040032]

**64. Pinan-Lucarre B, Tu H, Pierron M, Cruceyra PI, Zhan H, Stigloher C, Richmond JE, Bessereau JLC. Elegans punctin specifies cholinergic versus gabaergic identity of postsynaptic domains. Nature. 2014; 511(7510):466-470. This study identified the secreted protein punctin/madd-4 as a potent regulator of cholinergic and GABAergic synapse identity in C. elegans, and showed that differential expresssion of long and short isoforms controls coupling between pre-and postsyanptic domains. [PubMed: 24896188] 


\section{Highlights}

Molecular constituents of ionotropic neurotransmitter receptors in the brain

Receptor subunits responsible for synaptic localization of AMPAR and $\mathrm{GABA}_{\mathrm{A}} \mathrm{R}$

Anchoring proteins for AMPARs and $\mathrm{GABA}_{\mathrm{A}}$ Rs at each synapse 
a

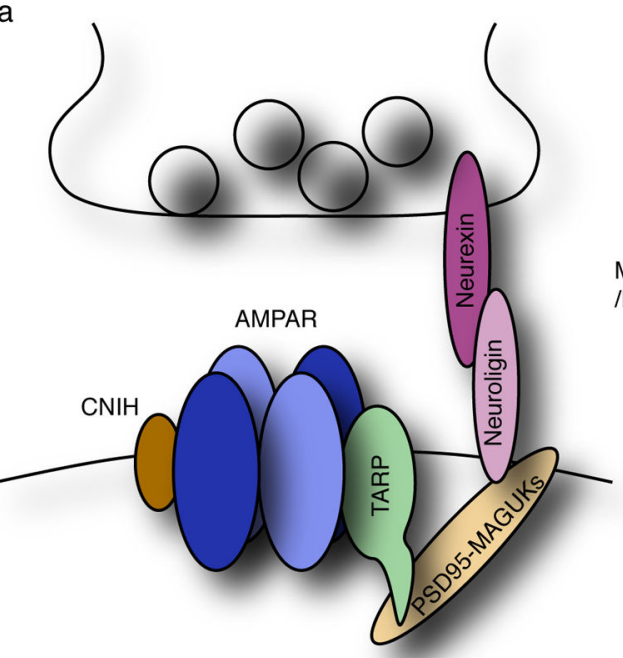

b

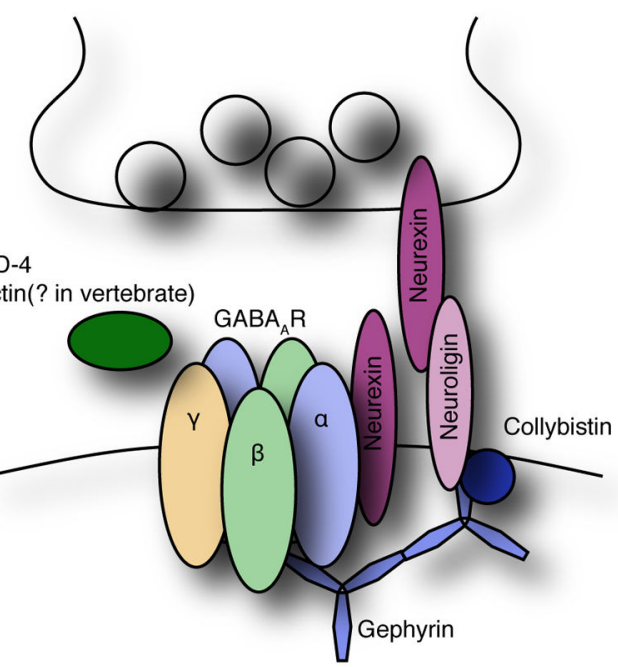

Figure 1. Organization of AMPA receptor synapses and $\mathrm{GABA}_{\mathrm{A}}$ receptor synapses (a) AMPA receptors form a complex with TARPs and PSD-95 like MAGUKs, which also bind to neuroligins. (b) Synaptic localization of $\mathrm{GABA}_{\mathrm{A}} \mathrm{Rs}$ is modulated by neuroligin-2, neurexin, collybistin and gephyrin. 


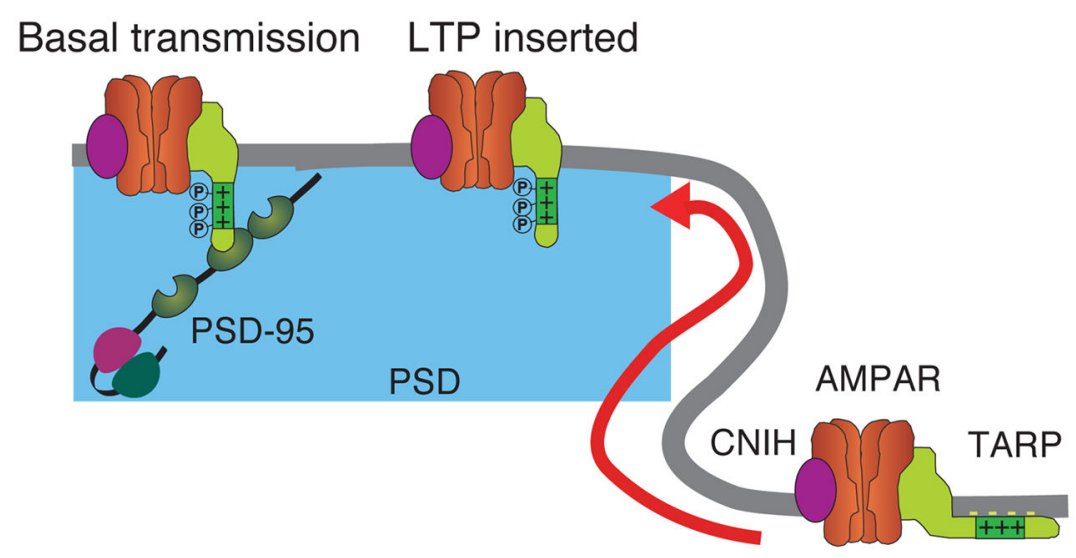

Figure 2. Synaptic localization of AMPA receptor complex in basal transmission and plasticity In the hippocampus, TARP forms a tripartite complex with TARPs and CNIH2/3. In basal transmission, TARP-dependent synaptic localization of AMPA receptors is mediated by interaction of the TARP $\gamma-8$ PDZ binding with PSD-95 like MAGUKs. During plasticity, AMPARs inserted into synapses independent of the TARP PDZ binding and PSD-95 MAGUKs. 